\title{
The Impact of Internal and External Factors on Commercial Bank Profitability in Jordan
}

\author{
Jamil J. Jaber ${ }^{1} \&$ Abdullah A. Al-khawaldeh ${ }^{2}$ \\ ${ }^{1}$ Department of Risk Management \& Insurance, The University of Jordan, Aqaba, Jordan \\ ${ }^{2}$ Department of Accounting, Hashemite University, Zarqa, Jordan \\ Correspondence: Jamil J. Jaber, Department of Risk Management \& Insurance, The University of Jordan, Aqaba, \\ Jordan.E-mail: j.jaber@ju.edu.jo
}

\author{
Received: January 13, 2014 \\ Accepted: March 5, $2014 \quad$ Online Published: March 21, 2014 \\ doi:10.5539/ijbm.v9n4p22 \\ URL: http://dx.doi.org/10.5539/ijbm.v9n4p22
}

\begin{abstract}
The primary focus of this paper is to address the determinants of profitability on commercial banks in Jordan and to examine to what extent the performance of commercial banks operating in Jordan are affected by internal and external factors of companies listed on the Amman Stock Exchange for Jordanian Banks between 2007 and 2012. Previous studies focused only on internal factors, namely, the banks' specific characteristics in Jordan. This study includes not only the internal factors, but also external factors, namely, macroeconomic and financial market structures. The question is whether there are significant impacts that can be gained from internal and external factors on ROAA. The internal factors of capital adequacy, liquidity ratio, and size are found to be significant as well as all the external factors in these models. A third multivariate model which includes both internal and external factors is included in this study but not in previous studies. This model is found to be significant.

As a result, this research gives deeper insights into determinants influencing the profitability of Jordanian commercial banks within the Jordanian environment.
\end{abstract}

Keywords: internal factors, external factors, multivariate model

\section{Introduction}

Over the last years a number of factors have contributed to increasing competition in the Jordan banking sector. One of the most important factors is deregulation, promoted by the Central Bank Directive on Banking and Financial Services, Operation and Supervision of credit institutions. This directive provides the competitive conditions for all Jordanian banking institutions. The factors that influence banks' profitability are important for stakeholders such as the central banks, governments, bankers associations, and other financial authorities as well as the managers of the banks. You can review the articles written by Pasiouras and Kosmidou (2007); Rajan and Zingales (1998); and Levine (1998).

The aim of this paper is to extend earlier works on the determinants of profitability of banks in Jordan. Then it examines to what extent the performance of commercial banks operating in Jordan market is affected by internal factors and external factors. Internal factors are the bank's specific characteristics. External factors are financial market structures and macroeconomic.

Bourke (1989) used international data from 1972-1981. He found that both liquidity and capital ratio were positively associated with profitability. Molyneux and Thorton (1992) examined the determinants of European banks profitability over the period 1986-1989. They found negative relationship between profitability and liquidity. Pasiouras and Kosmidou (2007) considered European banks from fifteen countries over the period 1995-2001. They found that profitability was positive relationship associated with real GDP.

The present study attempts to provide additional and more recent evidence on the determinants of commercial banks profitability in Jordan. This paper differs from the earlier mentioned studies in several aspects. First, it studies the Jordanian banking sector. Secondly, it includes more recent years in the analysis by examining the period 2007-2012.

The reminder of the paper is structured as follows. Section 2 provides a literature review of related studies. 
Section 3 presents the data and methodology used in this study. The empirical results are presented in Section 4. Finally, in Section 5 the concluding remarks are discussed.

\section{Literature Review}

Goddard et al. (2004) investigate the determinants of profitability in Spain, Italy, France, Denmark and the UK, for the period $1992-1998$. They found that the profitability was a positive relationship with the capital-assets ratio. Furthermore, the authors found a positive relationship between profitability with the importance of off-balance-sheet business in a bank's portfolio for the UK, but either neutral or negative elsewhere.

Kosmidou et al. (2006a) examine how domestic banks differ from foreign banks in the UK. It indicates the foreign banks are characterized by higher net interest revenue to total earning assets, return on equity, loans to customers and short term funding.

Vong and Chan (2006) investigate the impact of financial structures, macroeconomic variables and bank characteristics on the performance of the banking industry of Macau. The results showed that the quality of assets, as measured by loan- loss prevention, effects on the performance of banks negatively. In addition, the inflation rate showed a strong relationship to the performance of banks.

Pasiouras and Kosmidou (2007) investigate the profitability of foreign and commercial domestic banks in the 15 European countries over the period 1995-2001. It indicates the profitability of both foreign and domestic banks is impacted by the financial market structure as well as the bank's specific characteristics and the macroeconomic conditions. All the variables, with the exception of concentration in the case of domestic banks profits, are significant although their effect and relationship with profits is not always the same for domestic and foreign banks.

Chiorazzo et al. (2008) examine the performance of Italian banking markets. The results indicate the following: 1) the relation between non-interest revenues and profitability is stronger at large banks; 2) small banks can make gains from increasing non-interest income.

Khrawish (2011) investigates the performance of commercial banks in Jordan during the period from 2000-2010. The researcher found there are significant and positive relationships between ROA and the Bank Size, Total Equity/Total Assets ratio, Total Liabilities/Total Assets ratio, Net Interest Margin and Exchange Rate of the commercial banks. In addition, there are significant and negative relationships between ROA and Annual Growth Rate for GDP, and the Inflation Rate. Also, this study found that there are significant and positive relationships between ROE and the Bank Size, Total liabilities/ Total Assets, Net Interest Margin, Exchange Rate and Loan / Total assets. In addition, there are significant and negative relationships between ROE and Annual Growth Rate for Gross domestic product, and the Inflation Rate of the commercial banks.

Doumpos and Kosmidou (2012) used multi-criteria analysis methods such as a value function model, an outranking approach, and a cross efficiency technique to evaluate the financial performance of a sample of European banks over the period 2006-2009. The obtained results provide useful insights on the performance of the banks, the effects of the recent crisis, the relationship between bank performance and their size and country of origin as well as the stability of the evaluations over time and the factors that describe the dynamics of bank performance.

Ongore and Kusa (2013) investigate the impact of ownership structure on bank performance in Kenya. They used Generalized Least Square on panel data to estimates the parameters. They showed that the macroeconomic factors have insignificant contribution. In addition, the financial performance of commercial banks in Kenya is driven mainly by board and management decisions.

Lee and Hsieh (2013) investigate the impacts of bank capital on profitability and risk for 42 Asian countries over the period 1994-2008. The results indicate the following: 1) banks in low-income countries have a higher capital effect on profitability; 2) banks investments have the lowest and positive capital effect on profitability; 3 ) banks in Middle Eastern countries own the highest and positive capital effect on profitability.

Lee et al. (2014) examine the effects of revenue diversification on bank performance for 2,372 banks from 29 Asia-Pacific countries over the period between 1995-2009. This study found that the bank performance can be improved through diversification. In addition, under different financial systems the relationships between revenue diversity, financial reforms and bank performances are multidimensional. Financial reforms include interest rate controls, credit controls, entry barriers, banking supervision, privatization, and financial restrictions.

\section{Data Sources and Methodological Issues}

The source of research data for this study is from the Amman Stock Exchange (ASE) database, and the 
Department of Statistics (DOS) in Jordan. This paper studies 11 domestic commercial banks in Jordan from 2007 through 2012. The return on average assets (ROAA) is used to evaluate bank's performance. ROAA is the net profits expressed as a percentage of average total assets. It indicates how effectively the bank's assets are being managed to generate revenues.

In order to examine the external and the internal factors that impact the profitability of banks in Jordan, the following model has been developed by Pasiouras and Kosmidou (2007).

$$
Y_{i t}=b_{o i t}+b_{m i t} X_{m i t}+b_{d t} X_{d i t}+\varepsilon
$$

Where $\mathrm{i}$ refers to an individual bank operates in Jordan; $\mathrm{t}$ refers to year; $Y_{i t}$ is the dependent variable that refers to the return on average assets (ROAA) and is the observation of a bank $i$ in a particular year $t ; X m$ represents the internal factors of a bank; $X d$ represents the external factors of a bank; $\varepsilon$ is an error term.

$$
Y_{i t}=b_{0}+b_{i t}\left(E Q A S_{i t}+\operatorname{COST}_{i t}+L Q u i c k_{i t}+L S I Z E_{i t}\right)+b_{i t}\left(I N F_{i t}+\operatorname{ASSGDP}_{i t}+\text { MACPASS }_{i t}\right)
$$

The dependent variable $Y_{i t}$ refers to the return on average total assets of the bank. It is a functional of bank's profitability which calculated by dividing net income to total assets. It reflects bank's management ability to generate profits from assets. The independent variables are bank characteristics, the internal factors and the external factors.

The internal variable is calculated using: 1). EQAS is calculated as equity to total asset ratio. It is a measure of capital adequacy. It reflects the ability of a bank to absorb losses and handle risk exposure with shareholders. High capital-asset ratios are assumed to be indicators of low leverage and therefore low risk. 2). COST is the cost to income ratio. It provides information on the efficiency of management regarding expenses relative to the revenues it generates. Higher ratios imply a less efficient management. 3). LQuick is calculated as loans to customers and short term funding. It is a measure of liquidity. Higher figures denote lower liquidity. 4). Natural logarithm of size (LSIZE) is the accounting value of the bank's total assets.

Second, the external variable is calculated using 1). INF which is the annual inflation rate which calculated as annualized percentage change in a general price indexover time. It reflects the purchasing power per unit of money. 2). ASSGDP is the ratio total assets of the deposit money banks divided by the GDP (ASSGDP). It provides information on the overall level of development of the banking sector and measures the importance of bank financing in the economy. 3). MACPASS is the ratio stock market capitalization to total assets of the deposit in banks. This variable uses as a proxy of financial development as well as a measure of the size of the financial market and the relationship between bank and market financing.

\section{The hypotheses of this paper are:}

The main hypothesis is that there is no significant relationship between ROAA with internal and external variables of the Jordanian listed banks.

$\boldsymbol{H}_{\mathbf{0 1}}$ : There is no significant impact of capital adequacy on ROAA.

$\boldsymbol{H}_{\mathbf{0 2}}$ : There is no significant effect of the cost to income ratio on ROAA.

$\boldsymbol{H}_{\mathbf{0 3}}$ : There is no significant effect of the liquidity on ROAA.

$\boldsymbol{H}_{\mathbf{0 4}}$ : There is no significant effect of the natural logarithm of size bank ratio on ROAA.

$\boldsymbol{H}_{\mathbf{0 5}}$ : There is no significant effect of the INF ratio on ROAA.

$\boldsymbol{H}_{\mathbf{0 6}}$ : There is no significant effect of the ASSGDP ratio on ROAA.

$\boldsymbol{H}_{\mathbf{0 7}}$ : There is no significant effect of the MACPASS ratio on ROAA.

\section{Multivariate Regression Analysis}

We divide this analysis for three models: The first model was the ROAA with the internal factors. The second model was the ROAA with the external factors. The third model was the ROAA with aggregate internal and aggregate external factors. These models ware run with un-transformed data. We improve Durbin-Watson value and multicollinearity problem by transforming variables. These potential problems can be much reduced. The results of these models are explained in the following sections. 


\subsection{Ordinary Least Squares (OLS) Regression for the Internal Variables}

Table 1. Summary statistics of independent continuous internal variables

\begin{tabular}{cccccc}
\hline Descriptive stat./Variables & ROAA & EQAS & COST & LQuick & Size \\
\hline Mean & 0.0140 & 0.0906 & 0.1411 & 0.3992 & $3.61 \mathrm{E}+09$ \\
Median & 0.0141 & 0.0644 & 0.1131 & 0.4000 & $1.46 \mathrm{E}+09$ \\
Maximum & 0.0253 & 0.3870 & 0.4320 & 0.6300 & $2.39 \mathrm{E}+10$ \\
Minimum & -0.0017 & 0.0168 & 0.0268 & 0.2000 & $5.13 \mathrm{E}+08$ \\
Std. Dev. & 0.0057 & 0.0644 & 0.0919 & 0.0937 & $6.09 \mathrm{E}+09$ \\
Skewness & -0.3094 & 2.1654 & 1.1845 & 0.1539 & 2.640416 \\
Kurtosis & 3.2206 & 9.7658 & 4.1059 & 2.5507 & 8.471413 \\
Observations & 66 & 66 & 66 & 66 & 66 \\
\hline
\end{tabular}

The table 1 describes statistics of the ROAA and internal variables for commercial domestic banks in Jordan. We find that the mean of ROAA is $1.4 \%$, the maximum value is $2.5 \%$, the minimum is $-0.2 \%$ and standard deviation is $-31 \%$. The mean of capital adequacy ratio is $9.1 \%$, the maximum value is $39 \%$, the minimum is $1.7 \%$ and standard deviation is $6.4 \%$. The mean of the cost to income ratio is $14.1 \%$, the maximum value is $43.2 \%$, the minimum is $2.7 \%$ and standard deviation is $9.2 \%$. The mean of liquidity ratio is $39.9 \%$, the maximum value is $63.0 \%$, the minimum is $20.0 \%$ and standard deviation is $9.4 \%$. The mean of size is $3.61 \mathrm{E}+09$, the maximum value is $2.39 \mathrm{E}+10$, the minimum is $5.13 \mathrm{E}+08$ and standard deviation is $6.09 \mathrm{E}+09$.

Table 2. Correlation matrix for independent internal variables

\begin{tabular}{cccccc}
\hline & ROAA & COST & EQAS & LQuick & Size \\
\hline ROAA & 1.0000 & -0.4887 & -0.2043 & 0.0999 & -0.0665 \\
COST & & 1.0000 & 0.0913 & -0.4305 & -0.2570 \\
EQAS & & & 1.0000 & -0.0829 & -0.3294 \\
LQuick & & & & 1.0000 & 0.2476 \\
Size & & & & & 1.0000 \\
\hline
\end{tabular}

The table 2 appears the correlation matrix for dependent variable and independent internal variables. We found that the ROAA has a negative correlation with COST equal $49 \%$, a negative correlation with EQAS equal $20 \%$, a positive correlation with LQuick equal $10 \%$ and a negative correlation with Size equal $7 \%$. Also, we found that the Cost has a negative correlation with EQAS equal 9\%, a negative correlation with LQuick equal $43 \%$ and a negative correlation with Size equal $26 \%$. In addition, the EQAS has a negative correlation with LQuick equal $8 \%$ and a negative correlation with Size equal 33\%. Finally, there is a positive correlation between LQuick and Size equal $25 \%$. So, there is no multicollinearity problem between the continuous independent variables; this means that the explanatory variables are sufficiently independent of one another.

Table 3. Full regression models between ROAA and internal variables

\begin{tabular}{lllll}
\hline Variables & $\begin{array}{l}\text { Untransformed (U-OLS) } \\
\text { Coefficient }\end{array}$ & t-statistic & $\begin{array}{l}\text { Transformed (T-OLS) } \\
\text { Coefficient }\end{array}$ \\
\hline C (intercept) & 0.0336 & 2.3426 & 0.0089 & 1.1862 \\
EQAS & -0.0173 & $-1.6922^{*}$ & -0.0007 & -0.0888 \\
COST & -0.0334 & $-4.4694 * * *$ & -0.0478 & $-6.9184^{* * *}$ \\
LQuick & -0.0076 & -1.0149 & -0.0132 & $-1.9751^{*}$ \\
Size & -0.0005 & -0.7237 & 0.0001 & 0.1318 \\
Adjusted & & & & 0.4332 \\
R-squared & 0.2409 & & 1.6585 & \\
Durbin-Watson stat & 0.7726 & & $13.2279^{* * *}$ & \\
F-statistic & $6.1579 * * *$ & & \\
\hline
\end{tabular}

Note: $(1) * * *$ significant at $1 \%, * *$ significant at $5 \%, *$ significant at $10 \%$ level of significance. 
As indicated from Table above, the adjusted R-squares were around $24.1 \%$ for untransformed data, which improved to around $43.3 \%$ for the transformed data. The Durbin-Watson statistic was around 0.77 for untransformed data, which improved to around 1.7. Also, we found that there is a negative non-significant relationship between ROAA and capital adequacy (EQAS) for transformed data. So, we acceptH $\mathrm{H}_{01}$. Then we found there is a negative significant relationship between ROAA and the cost to income ratio (COST) for transformed data. So, we reject $\mathrm{H}_{02}$ at $1 \%$ level of significant. Next, we found there is a negative significant relationship between ROAA and liquidity ratio (LQuick) for transformed data. So, we reject $\mathrm{H}_{03}$ at $10 \%$ level of significant. Finally, there is a negative non-significant relationship between ROAA and total assets (Size) for transformed data. So, we accept $\mathrm{H}_{04}$.

\subsection{Ordinary Least Squares (OLS) Regression for the External Variables}

Table 4. Summary statistics of independent continuous external variables

\begin{tabular}{lllll}
\hline Descriptive stat./Variables & ROAA & INF & ASSGDP & MACPASS \\
\hline Mean & 0.0140 & 0.0958 & 0.1739 & 0.2910 \\
Median & 0.0141 & 0.0720 & 0.0790 & 0.2579 \\
Maximum & 0.0253 & 0.1884 & 1.2676 & 0.6792 \\
Minimum & -0.0017 & 0.0441 & 0.0238 & 0.0880 \\
Std. Dev. & 0.0057 & 0.0553 & 0.2905 & 0.1306 \\
Skewness & -0.3094 & 0.6802 & 2.7268 & 0.7510 \\
Kurtosis & 3.2206 & 1.7940 & 9.2910 & 2.9791 \\
Observations & 66 & 66 & 66 & 66 \\
\hline
\end{tabular}

The table 4 describes statistics of the ROAA and internal variables for commercial domestic banks in Jordan. We find that the mean of ROAA is $1.4 \%$, the maximum value is $2.5 \%$, the minimum is $-0.2 \%$ and standard deviation is $-31 \%$. The mean of inflation rate (INF) is $9.6 \%$, the maximum value is $18.8 \%$, the minimum is $4.4 \%$ and standard deviation is $5.5 \%$. The mean of the total assets of the deposit money banks divided by the GDP (ASSGDP) is $17.4 \%$, the maximum value is 1.27 , the minimum is 0.02 and standard deviation is $29.1 \%$. The mean of the stock market capitalization to total assets (MACPASS) is $29.1 \%$, the maximum value is $67.9 \%$, the minimum is $8.8 \%$ and standard deviation is $13.1 \%$.

Table 5. Correlation matrix for independent external variables

\begin{tabular}{lcccc}
\hline & ROAA & INF & ASSGDP & MACPASS \\
\hline ROAA & 1.0000 & 0.2738 & -0.0144 & 0.4081 \\
INF & & 1.0000 & 0.0168 & 0.1812 \\
ASSGDP & & & 1.0000 & 0.4967 \\
MACPASS & & & 1.0000 \\
\hline
\end{tabular}

The table 5 appears the correlation matrix for dependent variable and independent external variables. We found that the ROAA has a positive correlation with and INF equal 27\%, a negative correlation with ASSGDP equal $1 \%$, a positive correlation with MACPASS equal $41 \%$. Also, we found that the INF has a positive correlation INF with ASSGDP equal 2\% and a positive correlation with MACPASS equal $18 \%$. Finally, there is a positive correlation between ASSGDP and MACPASS equal 50\%. So, there is no multicollinearity problem between the continuous independent variables; this means that the explanatory variables are sufficiently independent of one another. 
Table 6. Full regression models between ROAA and external variables

\begin{tabular}{lllll}
\hline \multirow{2}{*}{ Variables } & \multicolumn{2}{c}{ Untransformed (U-OLS) } & \multicolumn{2}{c}{ Transformed (T-OLS) } \\
\cline { 2 - 5 } & Coefficient & t-statistic & Coefficient & t-statistic \\
\hline C (intercept) & 0.0066 & 3.7288 & 0.0016 & 3.4085 \\
INF & 0.0193 & $1.6730^{*}$ & 0.0207 & $-1.5818^{* * *}$ \\
ASSGDP & -0.0053 & $-2.1419^{* *}$ & -0.0049 & $5.6389^{* * *}$ \\
MACPASS & 0.0223 & $3.9654^{* * *}$ & 0.0270 & \\
Adjusted & 0.2267 & & 0.4197 & 1.8183 \\
R-squared & & & $16.4291^{* * *}$ \\
Durbin-Watson stat & 0.6851 & & \\
F-statistic & $7.3523^{* * *}$ & & \\
\hline
\end{tabular}

Note. (1) $* * *$ significant at $1 \%, * *$ significant at $5 \%, *$ significant at $10 \%$ level of significance.

As indicated from Table above, the adjusted R-squares were around $22.7 \%$ for untransformed data, which improved to around $42 \%$ for the transformed data. The Durbin-Watson statistic was around 0.69 for untransformed data, which improved to around 1.8. Also, we found that there is a positive significant relationship between ROAA and inflation (INF) for transformed data. So, we reject $H_{05}$ at $1 \%$ level of significant. Then we found there is a negative significant relationship between ROAA and the total assets of the deposit money banks divided by the GDP (ASSGDP) for transformed data. So, we reject $H_{06}$ at $10 \%$ level of significant. Finally, there is a positive significant relationship between ROAA and the stock market capitalization to total assets (MACPASS) for transformed data. So, we reject $H_{07}$ at $1 \%$ level of significant.

4.3 Ordinary Least Squares (OLS) Regression for Internal and External Variables

Table 7. Summary statistics of independent continuous internal and external variables

\begin{tabular}{lccc}
\hline Descriptive stat./Variables & ROAA & Internal factors & External factors \\
\hline Mean & 0.0140 & 21.9326 & 0.5607 \\
Median & 0.0141 & 21.7745 & 0.4359 \\
Maximum & 0.0253 & 24.4893 & 1.9935 \\
Minimum & -0.0017 & 20.6690 & 0.2152 \\
Std. Dev. & 0.0057 & 1.0122 & 0.3812 \\
Skewness & -0.3094 & 1.1611 & 2.3207 \\
Kurtosis & 3.2206 & 3.7088 & 8.3126 \\
Observations & 66 & 66 & 66 \\
\hline
\end{tabular}

The table 7 describes statistics of the ROAA and internal variables for commercial domestic banks in Jordan. We find that the mean of ROAA is $1.4 \%$, the maximum value is $2.5 \%$, the minimum is $-0.2 \%$ and standard deviation is $-31 \%$. The mean of aggregate internal variables (the capital adequacy ratio, the cost to income ratio, liquidity ratio, natural logarithm of size) is 21.9 , the maximum value is 24.49 , the minimum is 20.67 and standard deviation is 1.01 . We found that the mean of aggregate external variables (inflation rate, the total assets of the deposit money banks divided by the GDP, stock market capitalization to total assets) is 0.56 , the maximum value is 1.99 , and the minimum is 0.22 and standard deviation is 0.38 .

Table 8. Correlation matrix for independent internal and external variables

\begin{tabular}{lccc}
\hline & ROAA & Internal factors & External factors \\
\hline ROAA & 1.0000 & -0.1160 & 0.3796 \\
Internal factors & & 1.0000 & 0.4440 \\
External factors & & & 1.0000 \\
\hline
\end{tabular}

The table 8 appears the correlation matrix for dependent variable with independent internal and external variables. We found that the ROAA has a negative correlation with internal factors equal $12 \%$ and a positive correlation with External factors equal $18 \%$. Also, we found that there is a positive correlation with external 
factors equal $44 \%$. So, there is no multicollinearity problem between the continuous independent variables; this means that the explanatory variables are sufficiently independent of one another.

Table 9. Full regression models between ROAA and two categories, internal and external variables

\begin{tabular}{lllll}
\hline \multirow{2}{*}{ Variables } & \multicolumn{2}{c}{ Untransformed (U-OLS) } & \multicolumn{2}{c}{ Transformed (T-OLS) } \\
\cline { 2 - 5 } & Coefficient & t-statistic & Coefficient & t-statistic \\
\hline C (intercept) & 0.0539 & 2.5167 & 0.0300 & 3.2541 \\
Internal factors & -0.0020 & $-1.9333^{* *}$ & -0.0033 & $-2.8775^{* * *}$ \\
External factors & 0.0065 & $2.3729^{* * *}$ & 0.0110 & $4.3595^{* * *}$ \\
Adjusted & 0.0537 & & 0.2205 & \\
R-squared & & & 1.7794 \\
Durbin-Watson & 0.7830 & & $10.0549^{* * *}$ \\
stat & $2.8439^{*}$ & & \\
F-statistic & & & \\
\hline
\end{tabular}

Note. (1) $* * *$ significant at $1 \%, * *$ significant at $5 \%, *$ significant at $10 \%$ level of significance.

As indicated from Table above, the adjusted R-squares were around $5.4 \%$ for untransformed data, which improved to around $22.1 \%$ for the transformed data. The Durbin- Watson statistic was around 0.78 for untransformed data, which improved to around1.8. Also, we found that there is a negative significant relationship between ROAA and aggregate internal factors for transformed data. So, we reject main hypothesis at $1 \%$ level of significant. Then we found there is a positive significant relationship between ROAA and aggregate external factors for transformed data. So, we reject main hypothesis at $1 \%$ level of significant.

\section{Conclusion}

This study investigates the determinants of profitability of Jordanian banks under two headings: first, bank characteristics (internal factors) namely, capital adequacy, the cost to income ratio, liquidity calculated as loans to customers and the accounting value of the bank's total assets; second, macroeconomic and financial structures (external factors) namely, the annual inflation rate, the real gross domestic product growth, the ratio total assets of the deposit money banks divided by the GDP (ASSGDP), the ratio stock market capitalization to total assets of the deposit money banks and the ratio stock market capitalization to GDP. To achieve this array of modeling techniques is used to provide a more comprehensive picture. They include multivariate analysis.

The results demonstrate that internal factors have a significant impact but not capital adequacy and liquidity ratio for the transformed model, while size is insignificant for the transformed and untransformed models. With respect to externally factors, inflation, total assets of the deposit money banks divided by the GDP, and stock market capitalization to total assets are significant associated with transformed and untransformed models. Nevertheless, the study finds a significant impact between internal and external factors in the third model.

\section{References}

Barth, J., Caprio, G., \& Levine, R. (2006). Rethinking Bank Regulation: Till Angels Govern. Cambridge: Cambridge University Press. http://dx.doi.org/10.1002/jid.1368

Barth, J., Caprio, G., \& Levine, R. (2008). Bank regulations are changing: for better or worse? Comparative Economic Studies, 50(4), 537-563.

Bourke, P. (1989). Concentration and other determinants of bank profitability in Europe, North America and Australia. Journal of Banking and Finance, 13, 65-79.

Chiorazzo, V., Milani, C., \& Salvini, F. (2008). Income Diversification and Bank Performance: Evidence from Italian Banks. Journal of Financial Services Research, 33(3), 181-203. http://dx.doi.org/10.1007/s10693-008-0029-4

Coccorese, P., \& Pellecchia, A. (2009). Multimarket Contact and Profitability in Banking: Evidence from Italy. Journal of Financial Services Research, 35(3), 245-271. http://dx.doi.org/10.1007/s10693-009-0057-8

DePrince, A., Ford, W., \& Morris, P. (2011). Some causes of interstate differences in community bank performance. http://dx.doi.org/10.1007/s12197-009-9105-3.

Doumpos, M., \& Kosmidou, K. (2012). Performance Evaluation of European Banks Using Multicriteria Analysis Techniques. 
Gedajlovic, E., Shapiro, D., \& Buduru, B. (2003). Financial Ownership, Diversification and Firm Profitability in Japan. Journal of Management and Governance, 7(3), 315-335. $\mathrm{http}: / / \mathrm{dx}$. doi.org/10.1023/A:1025029601562

Goddard, J., Molyneux, P., \& Wilson, J. O. S. (2004). The profitability of European banks: a cross-sectional and dynamic panel analysis. The Manchester School, 72(3), 363-381.

Hsieh, M. F., \& Lee, C. C. (2010). The puzzle between banking competition and profitability can be solved: international evidence from bank-level data. Journal of Financial Service Research, 38(2), 135-157. http://dx.doi.org/10.1007/s10693-010-0093-4

Karimzadeh, M., Akhtar, S. M., \& Karimzadeh, B. (2013). Determinants of Profitability of Banking Sector in India. Transition Studies Review, 20(2), 211-219. http://dx.doi.org/10.1007/s11300-013-0284-4

Khrawish, H. (2011). Determinants of Commercial Banks Performance: Evidence from Jordan. International Research Journal of Finance \& Economics, (81), 148-159.

Kosmidou, K., Pasiouras, F., Doumpos, M., \& Zopounidis, C. (2006). A Multivariate analysis of the financial characteristics of foreign and domestic banks in the UK. Omega, 34(2), 189-195.

Lee, C. C., Hsieh, M. F., \& Yang, S. J. (2014). The relationship between revenue diversification and bank performance: Do financial structures and financial reforms matter. Japan and the World Economy, 29, $18-35$.

Lee, C. C., \& Hsieh, M. F. (2013). The impact of bank capital on profitability and risk in Asian banking. Journal of International Money and Finance, 32, 251-281.

Lepetit, L., Nys, E., Rous, P., \& Tarazi, A. (2008). Bank income structure and risk: an empirical analysis of European banks. Journal of Banking and Finance, 32(8), 1452-1467.

Levine, R. (1998). The legal environment, banks, and long-run economic growth. Journal Money Credit Bank, $30(2), 596-613$.

Maudos, J., \& Solís, L. (2011). Deregulation, liberalization and consolidation of the Mexican banking system: effects on competition. Journal of International Money and Finance, 30(2), 337-353.

Mobarek, A., \& Kalonov, A. (2014). Comparative performance analysis between conventional and Islamic banks: Empirical evidence from OIC countries. Applied Economics, 46(3), 253-270.

Ongore, V. O., \& Kusa, G. B. (2013). Determinants of Financial Performance of Commercial Banks in Kenya. International Journal of Economics and Financial Issues, 3(1), 237-252.

Palia, D., \& Porter, R. (2004). The Impact of Capital Requirements and Managerial Compensation on Bank Charter Value. Review of Quantitative Finance and Accounting, 23(3), 191-206.

Pasiouras, F., \& Kosmidou, K. (2007). Factors influencing the profitability of domestic and foreign commercial banks in the European Union. International Business and Finance, 21(2), 222-237.

Peni, E., \& Vähämaa, S. (2012). Did Good Corporate Governance Improve Bank Performance during the Financial Crisis? Journal of Financial Services Research, 41(2), 19-35. http://dx.doi.org/10.1007/s10693-011-0108-9

Rajan, R. G., \& Zingales, L. (1998). Financial dependence and growth. The American Economic Review, 88(1), 559-586.

Ramadan, I. Z., Kilani, Q. A., \& Kaddumi, T. A. (2011). Determinants of Bank Profitability: Evidence from Jordan. International Journal of Academic Research, 3(4), 180-191.

Sanyal, P., \& Shankar, R. (2011). Ownership, competition, and bank productivity: an analysis of Indian banking in the post-reform period. International Review of Economics and Finance, 20(2), 225-247.

Shen, C. H., \& Lee, C. C., (2006). Same financial development yet different economic growth: why? Journal of Money, Credit and Banking, 38(7), 1907-1944. http://dx.doi.org/10.1353/mcb.2006.0095

Sinkey, J., \& Nash, R. (1993). Assessing the riskiness and profitability of credit-card banks.

Vong, P. I., Chan, H. S., (2006). Determinants of Bank Profitability in Macau. Journal of Banking and Finance.

Webster, A. (1997). The impact of technological change on bank performance. Journal of Economics and Finance, 21(3), 41-47. http://dx.doi.org/10.1007/BF02929037 


\section{Copyrights}

Copyright for this article is retained by the author(s), with first publication rights granted to the journal.

This is an open-access article distributed under the terms and conditions of the Creative Commons Attribution license (http://creativecommons.org/licenses/by/3.0/). 